\title{
ASSESSING ECOTOURISM PRODUCT AT KUALA SELANGOR NATURE PARK, SELANGOR
}

\author{
Rohaizah Abd. Latif, Herindran Raja Sekaran, Munira Saaidin \\ UNITAR International University, Selangor, Malaysia \\ Chiew Boon Tian \\ Taylor's University, Selangor, Malaysia
}

\begin{abstract}
The purpose of this study is to determine the ecotourism products and conditions, the conditions of the resources such as the natural, physical, and the tourism support services and facilities available in the area and to analyse tourists' perceptions and expectation of the current ecotourism product at Kuala Selangor Nature Park. A semistructured and open-ended questions were posed to the tourists, Park Manager and members of the management team at the park. The findings indicated the issues and challenges faced by management of the park in its attempt to ensure that the best possible service would be provided to every visitors and also to ensure the selfsustainability of the park.
\end{abstract}

Key words: ecotourism products, nature park, services and facilities, visitors.

Cite this Article: Rohaizah Abd. Latif, Herindran Raja Sekaran, Munira Saaidin and Chiew Boon Tian, Assessing Ecotourism Product at Kuala Selangor Nature Park, Selangor, International Journal of Management, 11(12), 2020, pp 382-394.

http://iaeme.com/Home/issue/IJM?Volume=11\&Issue=12

\section{INTRODUCTION}

Kuala Selangor Nature Park was opened in 1987. With a width of 296 hectares that is separated to 2 main products: the 201-hectare wide Tropical Rainforest and the Mangrove Swamp Forest. The recreation centre is under the administration of the Malaysian Nature Society, which is the oldest and one of the most prominent environmental not for profit, nongovernmental organisations in Malaysia. Thus, the park area is protected with no living species harm that has been the dedicated inhabitants here. Nature Park has the idea of Bird Park, whereby the guests can see with their own eyes the numerous types of wild flying creatures. The winged animal natural surroundings are as often as possible utilized as research for intrigued researchers and travellers. There are 156 types of feathered creatures and 57 of it are fowls from abroad like Russia and Siberia. In 1997, the nature park was perceived as an 
Important Bird Area (IBA) by Birdlife International (once in the past known as the International Council for Bird Preservation).

\subsection{Research Issues and Problems}

The earliest tourism concept was introduced by Feuler in 1905 when he contended that tourism emerged from the interconnection amongst tourists, business suppliers, governments and communities. The tourism industry developed then as a result of the peoples need to spend their own time away from home. This would involve such activities as recreation, relaxation, and pleasure, using the tourism services structures and products provided. According to Kiper (2013), ecotourism encompassed travelling to uncontaminated or undisturbed natural areas with the objectives of studying, admiring and enjoying the scenery with the flora and fauna, including appreciating cultural aspects of these areas (Weaver 2014). Funnel, David A. (2016) added that ecotourism could be defined as a sustainable form of tourism which is natural resource-based that focused primarily on the provision of learning and experience about nature. Thus, ecotourism sites should be managed in such a way that it would be non-consumptive, low-impact and locally oriented.

As pointed by Smith (1989), Couture (2002) and Dehoorne and Transler (2007) the challenge of ecotourism is to establish a dynamic balance between economic and social development of the affected destinations and ecosystem sustainability, taking into account the needs of host communities and building the conditions for a meeting between the populations "hosts" and "invited".

For nature-based tourists, experiences that incorporate geographical features with biological and cultural factors are considered more holistic because they integrate components of the ecosystem and human activity". While for learning experience, tourists are expected to experience scope-holistic elemental, orientation, involvement, education source and participant skill level.

Potential problems such as degrading of nature, biodiversity and environment of ecotourism destinations may arise due to unexisting managed tourism activities. As a form of development, tourism is relatively human-intensive resource. However, ecotourism sites may face a situation where the economic benefits tend to be offset by social and environmental costs for host communities, causing critical relationship between tourism development and the natural environment. These relationships can be problematic because the natural environment is both a factor of production and a source of attraction for tourists (Ayachi and Jaoudi, 2017). The general interdependent relationships between tourism and the environment indicate the need for a system approach to the management of economic with nature and environmental resources when analysing the perspectives of ecotourism for Kuala Selangor Nature Park.

Related to the issues mentioned would be the availability of resources such as funding, manpower capability, and interest of the local authority in sustaining the ecotourism sites. As an example, in the district of Kuala Selangor, there are a variety of ecotourism attractions such as the Firefly and the Nature Park, issues such as land clearing and heavy traffic flow had disturb the habitat, mangrove swamp, and wildlife in those areas and also the disturbance to the local communities..

\subsection{Study Objective}

The main objective of this research is to determine the current ecotourism products/services available at the Kuala Selangor Nature Park(KSNP) and to analyse the conditions of the facilities and infrastructure. The findings could instil the need for local government, local state tourism, travel marketer, and tourism trade entrepreneur to support the development, 
maintenance, and coordinate in the promotion of the ecotourism destinations to ensure their sustainability for future generations.

Specifically the study objectives entail :

- To determine the facilities and services available at Kuala Selangor Nature Park.

- To assess the conditions of the resources such as the natural, physical, and the tourism support services and facilities available in the area.

- To assess whether the environment and the site affected by the current touristic activities at the site.

- To analyse the tourists' perceptions and expectation of the current ecotourism products.

- To recommend new ecotourism products/services that can be offered and the target tourists market segments.

\subsection{Research Framework}

The research framework provides the systematic means for analysing the perspective of ecotourism at Kuala Selangor nature Park. The study began by analysing the condition of the resources such as the natural and physical, the tourism support services and facilities available in the area to determine the attractiveness of the site to draw in tourists. This was followed by the determination of the ecotourism products and services that could be offered. In the case of the Nature Park, there were already current products and services offered, so the challenge was to determine the conditions and popularity of those product/services, and possibly the suggestions on new products/service to be added. The study had also identified the type of tourists/visitors, the packages offered and the possible new promotional channels to attract new tourists based.

\section{Research Framework of the study}

Assessing the Perspectives of Ecotourism at the Kuala Selangor Nature Park, Selangor

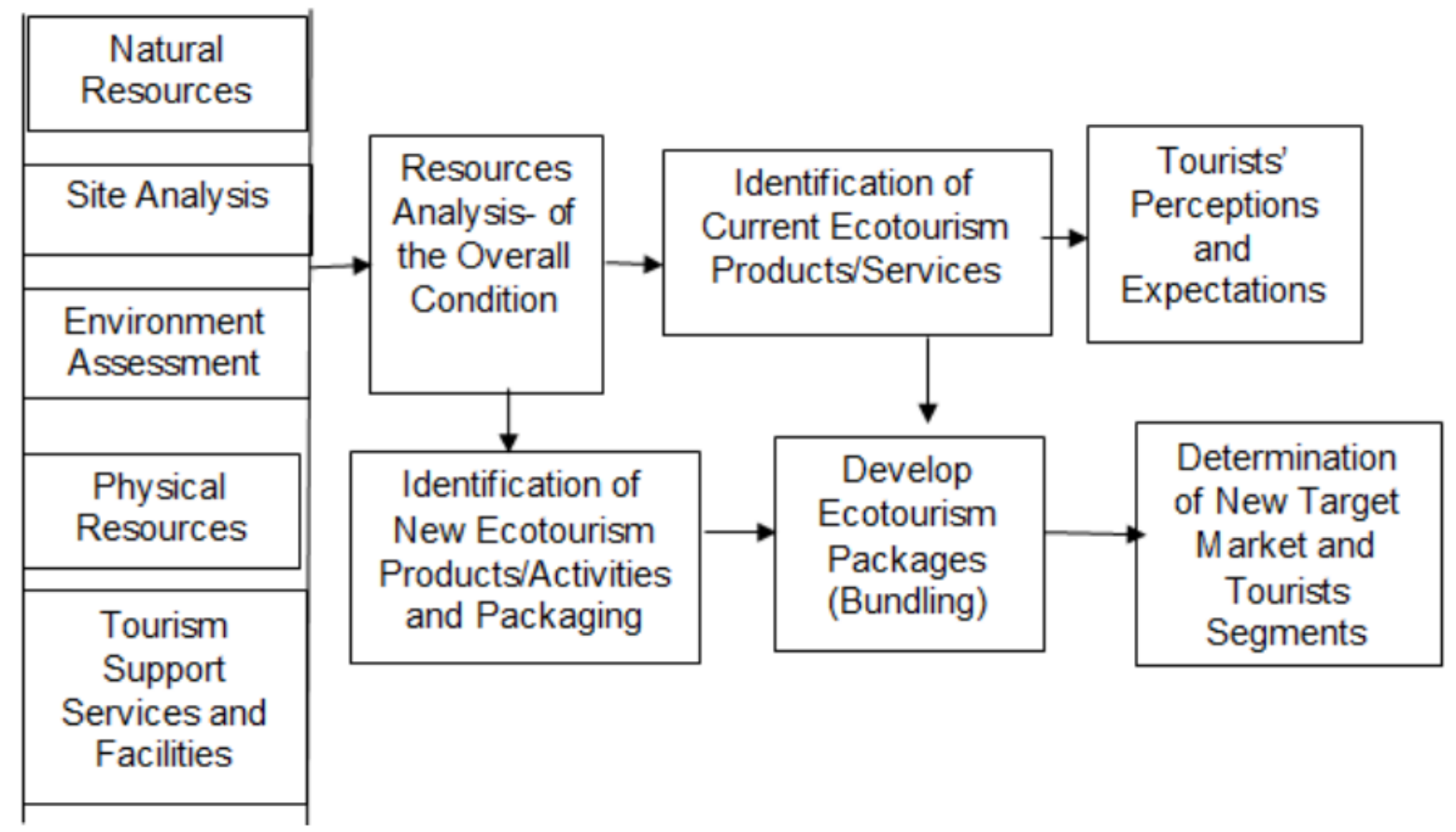

Figure 1 


\section{LITERATURE REVIEW}

The term ecotourism was defined in 1983 by "Hector Ceballos Lascurain" as a nature-based travel to relatively undisturbed areas with an emphasis on education. The expression was supported by Kocevski (2010)where he stated that ecotourism as a nature-based travel to generally undisturbed nature territories with an accentuation on instruction of considering, appreciating and getting a charge out of view and its wild creatures and plants. Visitor will appreciate these exercises simultaneously they are presented to the earth of a place of interest. They are inspired to plant trees and green plants in those lodgings where they remain and puts, they visit, exhorted not to take care of creatures while visiting zoo and prompted not to consume blazes while they are appreciating the excursion to a wild timberland. Ecotourism destination often have unique natural attractions A natural attraction is an attraction that has been created by nature. Many of these areas have been given a status to protect their environment and provide facilities so that the public are able to enjoy the sights.

Ecotourism had been designated by United Nations World Tourism Organization (2016) as the mixture of the individuals exercises that included travelling or remaining in places outside of their usual condition for not more than one consecutive year, with the purpose of recreation, business or other reason. Ecotourism represented a unique form of travel since for relaxation to occur, the site had to be developed. An individual would start his trip with one destination in mind, but would move to another location through the use of some means of transportation such as a car, van, or train to complete his excursion. Ecotourism involved an action when an individual becomes a visitor when he eagerly leave his typical environment to visit another area which is able to draw him (Camilleri, 2018).

In addition, Jurowski (2015) identified nature and ecotourism experience classification schema as three concepts: "nature-based", "learning" and "physical characteristics". For nature-based, the author argued that "experiences that incorporate geographical features with biological and cultural factors are considered more holistic because they integrate components of the ecosystem and human activity". For learning, tourists are expected to experience scopeholistic elemental, orientation, involvement, education source and participant skill level. Under physical characteristics, the ecotourism scheme is classified by nearness to roads, degree of naturalness and facilities. Eco tourism destination contains several components that attract visitors and meet their needs during visitation. It defines as outdoor activities, physical settings and social/cultural attributes, catering, natural landscape, accessibility and touristic information (Verbeke, 2016). On the other hand, Kothari and Anurag (2011) additionally called ecotourism as supportable the travel industry which could be characterized as an assortment of movement rehearses, yet everything boils down to a general arrangement of thoughts.

Ecotourism is also a piece of ecological protection and understanding what the necessities of the individuals who are nearby to the zone so they can be assisted with improving their personal satisfaction.

\section{RESEARCH METHODOLOGY}

Qualitative, case study approach has been adopted since the design allowed for an in-depth investigation of the ecotourism site. Observations were made on the behaviour and flow of tourists during the different period such as weekends, weekdays and public holiday to determine the variation in capacity usage and also to ascertain the type of of tourist / locals in the destination. The study was carried out for two months in order to detect patterns. 
The study was mainly focused at Kuala Selangor Nature Park, with the main purpose to understudy how the park is managed innthe the perspectives as ecotourism destination. The information gauge from the study will lead to an understanding of the local and visitors on why ecotourism is important and will help the park management to maintain, sustain and preserve the park.

Kuala Selangor Nature Park was selected because it consisted all the elements of a nature tourism site such as the natural resources, a well-defined site, different environment such as mangrove swamp, secondary forest, surrounding communities and the availability of, physical resources and tourism support, services and facilities. Tourists flow could easily be traced with the amount of time spent at each attraction. There was some form of crowd control system in place

Tourist and locals were used as the sample in this study. Convenience sampling was used in this research to approach the participant because this sampling is nonprobability sampling method where the sample in taken from a group of people which easy to contact or reach. A total of 11 participants involved and it was sufficient to gain information The targeted population were residents, visitors and tourists during the research exploration. Before conducting the interview, the participants were approached and brief on the research study, objectives and importance of ecotourism destinations and activities.

The primary data was collected on the site through interview and observation instruments whereby secondary data was collected through journals and online websites. The observation data collected were analysed for the finding and discussion. The interview session with systematic procedure which took place at Kuala Selangor Nature Park was conducted on different days and time to attain required data. The interview was conducted with an openended question which was designed to accommodate the data as the research objective. This relates to the concept of data saturation, which at a point there were no new data or information were collected in the data findings from the conclusion of the additional interview session, is a valuable one in determining the sample size. Observations also been conducted to analyse the objective from difference duration of period (weekends, weekdays and public holiday) to examine the potential of tourist / locals in the destination.

The study analysed the resources and the overall conditions of the resources at the Nature Park The following were the resources and the checklist items for use to guide in the data collection:

Instrument 1: Natural Resources Analysis checklist comprised of the assessment of the following: Wildlife, Rivers, Swamps, Forest/Jungle, Sea etc. The assessment focused on the overall condition of the resources, the area size, the types of activities carried out at the site, the types of tourist who visited the area (if any), and the economic or business activities carried out.

Instrument 2 : Environmental Assessment comprised of an analysis of potential for ecological damage; pollution - rivers, coastal area, Others; Preservation Needs, Conservation needs of marine life, Increase number of visitors will affect the area. Components: Soil, Plant life, Animal life, Coral Reef, Water/Sea, Coastal area, Water supply, Historical, Archeological buildings/features, Scenery changes, Others

Instrument 3: Site and Location Analysis checklist comprised of the following: Area Economics - featuring the assessment of business activities, transport availability for outsiders and within the area, special features and attraction, the distance to other the tourism attraction, and area size: Physical characteristics - featuring the assessment of drainage system and solid waste disposal system: Size and shape - featuring the area size of the build-up area and the availability for parking space. Utilities Availability: Street Patterns - featuring the assessment of the overall condition and the accessibility to the area: Positional characteristics - featuring 
the assessment of the distance and driving time to various important areas: Traffic Information - featuring the assessment of the traffic flow and the estimation of the vehicles in the areas: People traffic information: Visibility of the area - featuring the assessment of the road sighs and the availability of the local map as direction of the site: Pollution - featuring the assessment of the air, noise, water and environment pollution: Local Labour - featuring the assessment of the supply of the labour, the ethnicity of the labour and types of labour skills: and Other services - featuring the assessment of the other availability services such as police station, fire bridge, court house, hospital, post office, banks, money changer and business association.

Instrument 4: Cultural Resources Analysis checklist comprised the assessment of the following: Bukit Melawati - Historical Buildings, Historical Sites, Monuments, Archaeological Site and collection, Folklore and Tradition, Handicrafts, Museum, and Research Centre.

Instrument 5: Community Resources Analysis checklist comprised of the assessment of the following: Surrounding Community, Population density, perception on the Nature Park and its development, Community ethnic Background, Major Income source, Recreational Activities and Major Household transportation Mode.

Instrument 6: Tourism Facilities and Services

\subsection{Tourism Services and Facilities}

An analysis of Number of Rooms available, Type and quality of facilities, Ethnic of workers, Number of Seating Capacity, Quality of Surrounding

Elements: Accommodations: Hotels, Resorts, Chalets, Homestays, Small hotels, Others; Restaurants: Family, Fast food, Stalls, Others: Tour Guides, Shopping, Recreation Facilities, Entertainment Facilities

\section{STUDY FINDINGS}

\subsection{Respondents Profiles}

Table 1

\begin{tabular}{|l|l|l|l|l|l|}
\hline \multicolumn{1}{|c|}{ Participant } & \multicolumn{1}{|c|}{ Gender } & Age & Tourist/Local & \multicolumn{1}{|c|}{ Occupation } & \multicolumn{1}{|c|}{ Education } \\
\hline Participant 1 & Male & 28 & Tourist & Private & University \\
\hline Participant 2 & Male & 34 & Local & Government & University \\
\hline Participant 3 & Female & 25 & Tourist & Government & University \\
\hline Participant 4 & Female & 42 & Local & Government & $\begin{array}{l}\text { Secondary } \\
\text { school }\end{array}$ \\
\hline Participant 5 & Male & 38 & Tourist & Private & University \\
\hline Participant 6 & Female & 32 & Local & Government & University \\
\hline Participant 7 & Male & 34 & Tourist & Private & $\begin{array}{l}\text { Secondary } \\
\text { school }\end{array}$ \\
\hline Participant 8 & Female & 40 & Local & Government & $\begin{array}{l}\text { Secondary } \\
\text { school }\end{array}$ \\
\hline Participant 9 & Male & 42 & Local & Self employed & University \\
\hline Participant 10 & Female & 54 & Local & Self employed & $\begin{array}{l}\text { Secondary } \\
\text { school }\end{array}$ \\
\hline Participant 11 & Male & 30 & Tourist & Private & University \\
\hline
\end{tabular}

There were five (5) female participants and six (6) male participants among tourists and locals were participated in the study. The range of age is between 25 to 54 years. Six (6) participants are working in government sector, three (3) more participants are working in private sector and the other two (2) participanta are in self-employment operation. Seven (7) 
of the participants have studied until graduate level while four (4) of the participants have finished their studies until secondary school.

\subsection{Study Site: Kuala Selangor Nature Park}

Kuala Selangor Nature Park was opened in 1987. With a width of 296 hectares that is separated to 2 principle parts that is a 201-hectare wide Tropical Rainforest and the equalization is Swamp Forest. The recreation centre is under the administration of the Malaysia Nature Lovers Association. Thus, the normal marvels of the recreation centre are protected with no living space harm that has been the dedicated inhabitants here. Nature Park has the idea of Bird Park, whereby the guests can see with their own eyes the numerous types of wild flying creatures. The winged animal natural surroundings are as often as possible utilized as research for intrigued researchers and travellers. There are 156 types of feathered creatures and 57 of it are fowls from abroad like Russia and Siberia. In 1997, the nature park was perceived as an Important Bird Area (IBA) by Birdlife International (once in the past known as the International Council for Bird Preservation).

\subsection{Site Map}

Table 2

\begin{tabular}{|c|c|c|c|}
\hline $\begin{array}{l}\text { A. Mangrove } \\
\text { Swamp }\end{array}$ & $\begin{array}{l}\text { B. Mangrove Extended } \\
\text { Wooden Walkway }\end{array}$ & $\begin{array}{l}\text { C. Forest/Jungle } \\
\text { area }\end{array}$ & D. Jungle Trail \\
\hline E. Camping Area & F. A-Frame tents & G. Hostel Block & $\begin{array}{l}\text { H. Gazebo - } \\
\text { rest area }\end{array}$ \\
\hline $\begin{array}{ll}\text { I. } & \text { Observation } \\
& \text { Tower }\end{array}$ & J. $\quad$ Rope Bridge & K. Visitors Zone & $\begin{array}{l}\text { L. One-way } \\
\text { footpaths }\end{array}$ \\
\hline
\end{tabular}

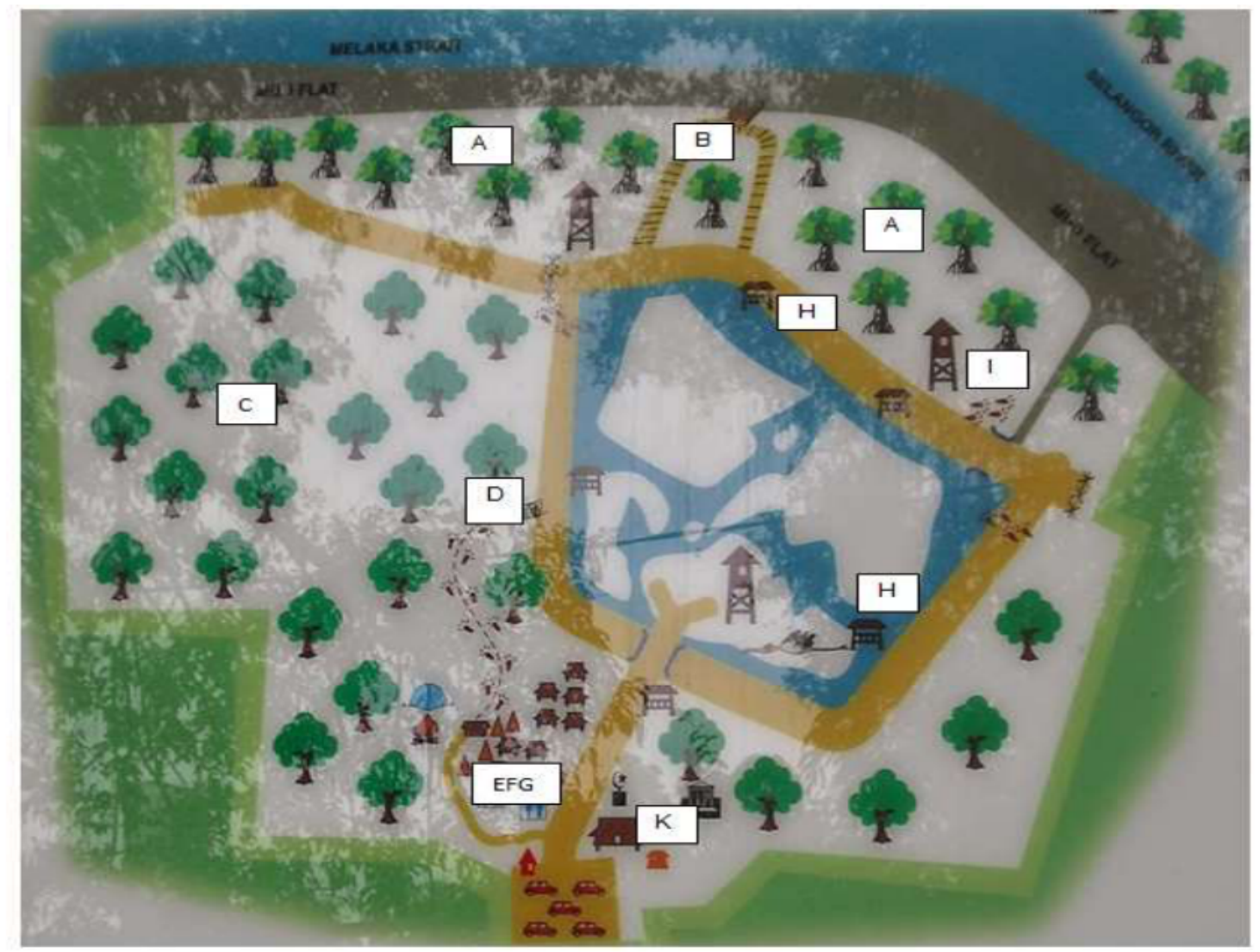

Figure 2 


\subsection{Assessment based on Observations on the Resources and on the Overall Conditions of the Resources}

\subsubsection{Nature Resources}

The Mangrove Swamp Area

- Walking Path

- Bird Watch Tower -migratory birds

- Hanging Bridge

\subsubsection{Nature-Related Activities}

- Jungle tracking

- Replanting Mangrove plants

- Bird watching

- Camping

- Group/Educational Tour

- Gotomg-Royong cleaning up activities

\subsubsection{Forest area, Types of vegetation and trees, Wild life, and the Flora and Fauna}

Occupying over 2.9 square kilometers, the park comprises three distinctive habitats - a brackish water lake system, mangrove forest and secondary forest.

A brackish water lake system - The park's 20-acre man-made lake serves as a place for birds to roost and feed. It is also a nesting area for approximately 156 bird species, 57 of which are migratory. There are several observation towers and bird hides around the lake where visitors can spot eagles, bee-eaters, kingfishers and others more, In the lake some vegetations are grown such as kangkong, yam and lotus plants and also snails, prawns and fish can be found here, however fishing is not allowed.here. For visitors who wish to walk around, a walking/Hiking trails: of $1.7 \mathrm{~km}$ is provided

Mangrove forest - Up to 13 species of mangrove trees from 4 different families thrive in this 95-hectare mangrove forest. The mangrove swamp in Kuala Selangor Nature Park is a great place to get a quick education on what mangrove forests really are, and to observe the myriad life forms that call that forest their home. With most mangrove swamps under threat due to having next to no protection status, the mangement fulfils an important role in the conservation of this valuable ecosystem. The Mangrove Walkway ( 1.5 kilometers) brings visitors through a swamp into the heart of the mangrove forest and takes about 55 minutes to complete. .

Secondary forest. and Conservation activities - The secondary forest is also separated from the lake by another bund and ditch. This secondary forest looks poor in tree species and contains a lot of fig trees. It is also home to many long-tailed macaques, and mosquitoes by the legion (so strong insect repellent is a must if you don't want to be feasted on alive!) However, once you are out of the secondary forest, you emerge onto more open terrain walking across the man-made bund, where the number of mosquitoes drops dramatically, and somewhere around the middle of the track, overlooking the lake, is a concrete lookout tower. From here, you can spend a whole day observing the various species of herons and storks that make the lake their home; in fact the lake was created to attract them to come. A threatened species of stork, the Milky Stork, roosts at the lake. Eagles are also frequently spotted in the skies above 


\subsubsection{Site and Surrounding Community}

The nature park occupied over 2.9 square kilometers, Kuala Selangor Nature Park comprises three distinctive habitats -

A brackish water lake system - The park's 20-acre man-made lake serves as a place for birds to roost and feed. It is also a nesting area for approximately 156 bird species, 57 of which are migratory. There are several observation towers and bird hides around the lake where visitors can spot eagles, bee-eaters, kingfishers and others more, In the lake some vegetations are grown such as kangkong, yam and lotus plants and also snails, prawns and fish can be found here, however fishing is not allowed.here. For visitors who wish to walk around, a walking/Hiking trails: of $1.7 \mathrm{~km}$ is provided

Mangrove forest - Up to 13 species of mangrove trees from 4 different families thrive in this 95-hectare mangrove forest. The mangrove swamp in Kuala Selangor Nature Park is a great place to get a quick education on what mangrove forests really are, and to observe the myriad life forms that call that forest their home. With most mangrove swamps under threat due to having next to no protection status, the KSNP fulfils an important role in the conservation of this valuable ecosystem. A concrete boardwalk leads out to the open sea, passing through the mangrove forest proper, where many kinds of mangrove trees with their stilt roots like Rhizophora apiculata, Rhizophora mucronata, Sonneratia and Bruguiera species dominate. This forest has a main canopy of about 15-20 meters in height. The walking/ hiking trails which is $1.5 \mathrm{~km}$ brings visitors through a swamp into the heart of the mangrove forest and takes 55 minutes to complete.

Surrounding Community - Kuala Selangor Nature Park situated just off the town of Kuala Selangor, a town on the coast of Selangor. It sits at the foot of Bukit Melawati, a historical hill with the remains of an old fort overlooking the mouth of the Selangor River. The area is surrounded by the shop lot in the town area and residential area. A little further up the Selangor river is a village called Kampung (Village)Belimbing, where the famous firefly park of Kuala Selangor. This area is famous for its many fireflies that put on a spectacle of light after dusk; in fact, the fireflies are the main attraction for many tourists to visit Kuala Selangor. The Berembang trees that line the riverbank here provide a suitable habitat for these fireflies; their preservation and general conservation of the brackish riverine forest here is important to maintain the firefly population from extinction.

\subsubsection{Tourism Facilities and Services}

Visitor Centre - the centre is open 7 days a week including public holidays from 0900 to 1800. Visitor can purchase T-shirts, souvenirs and Malaysia Nature Society books/merchandise here. here. Slide shows on mangrove ecology, conservation and other Park related activities are available on request.

Ticketing Booth - located in the visitor centre as visitor enter the centre. A medium size ticket counter and manned by two staffs. Due to its size it won't be able to cater to big groups, normally the tourist guide or group leader will liase at the ticket counter to avoid congested at the booth.

\section{Rest Areas and Restrooms}

Ample rest area is provided to tourists with capacity of 30 people and restrooms are available for tourists. The restrooms are kept clean at all times. However the restroom provided are the traditional restrooms and not seated restrooms.

\section{Seminar Hall}

An air-conditioned hall equipped with basic facilities with accommodation for approximately 80 people maximum is also available to rent. 


\section{Parking facilities}

Ample parking facilities were provided with area for tour buses to unload passengers

\section{Accommodation}

There are 4 A-frame huts, 8 chalets, 2 dormitories, a hostel with a common dining hall.

\subsection{Tourists' Perceptions and Expectations on the facilities}

The research findings could provide information and help in the planning of the park pertaining to managing the facilities, tourists activities and rate of facilities usage.

Participants (4), (8), (10) and (11) noted that the nature park were equipped with tourists' facilities activities such as walking bridge, bird watching tower, resting area and walking and hiking trails, However some of the facilities such as resting area inside the park, walking bridge into the mangrove forest and the bird watching tower need to be upgraded as the conditions of the facilities are not in good conditions such as some part of the hanging bridge need to be repaired, as some part of the wooden lookout tower was decaying. The mangrove walkway railing need to be repaired as some railings were missing. Participants (3), (6), (7) and (9) shared the similar feedback that some facilities need to be repaired, some of observation towers which cannot be accessed because of the stairs were missing. The repairing work is crucial to avoid any casualties at the park. The participants also mentioned the conditions of the board walk railings where some parts were missing which is dangerous especially for kids. Participant (7) who is a returnee and also work as tour guide shared his feelings that Kuala Selangor Nature Park is one of the beautifu nature park in Malaysia and the tourism activities in the park need to be managed properly, facilities need to be upkept and maintained from time to time in order to sustain Kuala Selangor Nature Park. The look-out bird watching towers allowed visitors to view different species of birds that passing through the area especially on their annual migration. Most of the toursits enjoy bird watching and perhaps one of the interesting activity at the park. Some of the look-out bird watching tower need to be repaired as the structures were in bad conditions. He also noticed that some signs were broken or damaged, without the sign visitors won't be able to go around the park themselves. He quoted that the nature park is clearly a park that has some good bits to see and good message to spread but need funding to do it properly. Participants (2), (3), (6) and (7) mentioned that Kuala Selangor Nature Park have has its own cheap accommodation with very basic facilities; For RM45 visitors can have a chalet to sleep for 3 persons for the night which has electric light and ceiling fan but no power points. There is a simple bathroom attached with only cold water and no toiletries, tissues or towels are provided which tourist or visitors have to bring their own one. The hotel rooms, resorts and chalets are well maintained and clean; public toilets are well maintained with eco-friendly services. There is a sundry shop at the nature park which sells only drinks and tidbits. If tourists need to buy foods, they can get them at Kuala Selangor town which is a walking distance from the nature park. They reckoned that there are ample of restaurants and café around the town area to dine in for local or western cuisine with reasonable pricing.

\subsection{Park's Manager Perspective}

According to the Park Manager, Kuala Selangor Nature Park is one of the best mangrove park and nature sanctuary in Malaysia. Since it's development as tourist site, it has attracted many visitors who are interested in nature tourism and environmental tourism. He mentioned that an average total of 2500 visitors visit Kuala Selangor Nature Park per month which consist of local, visitors and tourist. The maximum number of visitors at a time at Kuala Selangor Nature Park is 3000 visitors, whereby on public holidays, at least 500 tickets will be sold out with maximum 1500 capacity of local tourist to the park. 
Based on the layout of the facility, the information counter, ticket counter and gallery, around 20 people could enter conveniently at a time. Nevertheless during movement control order of Covid-19 pandemic, the number has reduced to only 10 people are allowed to enter at a time in view of social distancing. Public toilets are located in two places. One is near the information counter whereby the capacity of usage is 10 people at a time ( 5 for male and 5 for female toilet). Another public toilet is located near the animal show hall whereby 20 people can enter at a time (10 for male and 10 for female toilet). The animal show hall can accommodate maximum 40 people at a time to see the show.

There were two halls at Kuala Selangor Nature Park namely e the dining hall and multipurpose hall. Dining hall was used for dining purpose during huge events organised and food catering's location. Around 100 people can enter the dining hall at a time; however during Covid-19 pandemic, only 50 people are allowed to enter the hall at a time; whereby multipurpose hall is used for meeting, seminar, dine in and also for other purposes. There is also a public library at Kuala Selangor Nature Park which can accommodate 10 people at a time for public usage.

There are total of 3 bird watching towers in Kuala Selangor Nature Park. Only 1 main tower can accommodate 15 visitors at a time whereby the other 2 more towers only can accommodate 5 people at a time due to the condition of the tower. As the area of mangroves $\&$ mudflats which built in about 350 acres, the maximum numbers of tourist at a time is 60 people during normal days and 25 people during current situation covid-19. Secondary forest within 450 acres allows 70 visitors at normal days and 30 visitors due to current situation covid-19. Brackish lake within 25 acres allow capacity of 25 visitors on normal days and only 10 visitors are allowed during the current situation covid- 19 .

He mentioned that it is difficult to source financial for maintenance and upgrading of the facilities, as the nature park is under non-profit organisation like Malaysia Nature Society. According to him, the nature park received funding from international organisation for the last 10 years and before as Malaysia was a developing country. As the country become developed nation it is difficult to obtain funding as the priority will be given to the developing countries. Nonetheless, the nature park received some assistance from the state government especially during special visit from dignitaries or special event held at the park.

\section{CONCLUSION}

From the findings, Kuala Selangor Nature Park management maintain and preserve the beauty of the nature all the time. The management has worked hard to gain corporate sponsorship and financial support for the park which has helped to maintain the conditions of the park. Nature based activities such as jungle tracking and camping which are the popular activities at Kuala Selangor Nature Park were carried out with proper management without any adverse impact on the biodiversity, flora and fauna at the park. This was successful carried out by the park management by managing the number of visitors and group that come to the park. Normally group visit came through advance reservation as such it is easier to arrange and control the activities to ensure group and activities are not concentrate in one area but rather break up the group and activities are conducted differently in a smaller group. The special interest group like bird watching or biodiversity researchers normally come on week days, where it is not busy during this time hence it does not affect the area. The effective group managing and tour scheduling by the management has keep the adverse affect to the nature park at minimum level. The management also placed signages and instructions all around the park which informed the park visitors' the do's and don't and this helps keeping the park safe and clean and reduces abuse or pollution within the park. However some of the signages which were wornout as the writing can't be read and decay need to be repaired or replaced. 
The effective tour group managing and tour scheduling by the management has safe the park from adverse affect to the nature and biodiversity at minimum level.

In general, all participants are satisfied with the facilities provided at the nature park. Kuala Selangor Nature Park offers visitors with ecotourism activities such as hiking, trailing, bird watching, watching mangrove habitat, explore nature and night walk and provided facilities that support the activities. Some of the facilities however need to be repaired and upgraded due to the decay conditions of the facilities. Kuala Selangor Nature Park is a great nature place with beautiful view and offers a great nature experience where visitors are able to walk in Mangroove trese. Visitors are able to walk inside the jungle where they can see different types of trees. The par provided few spots of resting booth to rest when walking in the jungle. As for students the natural park provides good educational experiences to students as they could learn more on nature and appreciate them. They could see in real the nature living and mangrove tress and experience themselves. The visitors also want the management to repair some facilities which decayed and have come loose, this is important for the safety of visitors to the park. They also recommended the tour at the park would be more beneficial with a guide to make the experience more knowledgable and fulfilling.

\section{RECOMMONDATION}

Based on the research objective, research findings and researcher's observation, Kuala Selangor local authority and Kuala Selangor Nature Park Management should recommend new activities to attract more visitors / tourist to their places. Kuala Selangor Nature Park can organize cycling tour through out from Kuala Selangor town to other tourism destination within the district. Kuala Selangor Nature Park can offer a light jungle trekking adventure which is an ideal way to get a sense of what this magnificent ecosystem has to offer. The management should appoint a local guide who will highlight points of interest while going on the jungle tracking and bird watching.

Educational tours can be conducted for school students during school holidays for them to learn and understand what nature is, how important it is for the future and hidden history of Kuala Selangor. Local authority should organize different programs to boost economic activity, and sustainable development of the tourist attraction destinations. Hotel and resorts which operates around Kuala Selangor area should practice Innovative and sustainable by applying solar panels in their roof top. Management should give special attention to water management, biodiversity and reducing and recycling waste.

They should practice the $3 \mathrm{R}$ - reduce / recycle / reuse to save the nature. Cultural activities based on local culture, history and folklore and lectures on preserving Kuala Selangor Nature Park should be organized / advertised in website for people awareness. To sustain the current carrying capacity in Kuala Selangor Nature Park, more signage boards, and rules must be implemented.

Park staffs must monitor the tourist / visitor's movement from time to time by creating spacious place for them to move around without damaging the flora and also by placing signages like do not litter, don't make noise, don't plug the flowers and so on. During schools' holidays or public holidays, tree planting events can be organized for groups.

During public holidays, school holidays and weekends, Kuala Selangor Nature Park Management can organize an event like "buy and plant; it's like buying a plant in small amount and plant it in a designated area; saving the earth; so the area will get greener at the same time the fund will be used to improve the current services / products which are available in the park for better usage for the tourist. Kuala Selangor Nature Park Management should create a marketing plan to do their internet marketing. 
It helps them to achieve their goals, easy to track time keeping on what are they doing, why are they doing it and what's the result by doing it. Kuala Selangor Nature Park should post what are activates was held recently and what are the upcoming activities will be happening to attract more visitors in sense of participants. It's a way the management encouraging people to spend their time in a beneficial way at the same time promote the tourist destination.

\section{REFERENCES}

[1] Abdulaziz, M.Z., Abdul Aziz, Z.A. and Asmawi. (2009). Wetland Management of Kuala Selangor Nature Park, Malaysia. Proceeding of International Seminar on Wetlands and Sustainability: Wetland and Climate Change-The Needs for Integration. 26-28 June 2009. Pp. 77-98.

[2] Asker S, Boronyak L, Carrard N \& Paddon M.(2010), Effective Community Based Tourism: A Best Practice Manual. University of Technology Sydney, Sydney

[3] Awaritefe O. 2004. Motivation and other considerations in tourist destination choice: a case study of Nigeria. Tour Geogr.6:303-330.

[4] Ayachi H and Jaoudi S (2017), Problems and perspective of ecotourism in the Island of Farasan An empirical study based on survey data . Saudi Ar. Society and Business Review Vol. 12 No. 2, 2017 pp. 235-251

[5] Boo, E. (1990) Ecotourism: The Potentials and the Pitfalls (Vol. 1). World Wildlife Fund, Washington, DC

[6] Buckley, R. (2003) Case Studies in Ecotourism. CABI Publishing, Wallingford.

[7] Baum T, Chan J.K.L, (2007), Ecotourist' perception of ecotourism experience in lower Kinabatangan, Sabah, Malaysia, Journal of Sustainable Tourism, vol. 15, n 5, p. 574-590.

[8] Cater, E. (2004) Ecotourism: theory and practice. In A.A. Lew, C.M. Hall and A.M. Williams (eds) A Companion to Tourism. Blackwell Publishing, Oxford, pp. 484-497.

[9] Case Study of Kuala Selangor Nature Park, Malaysia. LAP LAMBERT Academic Publishing.

[10] Dekhili (2015) The perception of ecotourism Semantic profusion and tourists' expectations

[11] Jurowski, C. (2015), "Nature and ecotourism experience classification schema", International CHRIE Conference-Refereed Track, Vol. 27, available at:

[12] https://scholarworks.umass.edu/refereed/CHRIE_2010/Friday/27 (accessed 1 January 2017).

[13] https://www.intechopen.com/books/advances-in-landscape-architecture/role-of-ecotourism-insustainable-development. Retrieved 12 January 2020.

[14] Lambert L (2011). Case Study of Kuala Selangor Nature Park, Malaysia. Academic Publishing.

[15] Leroux, E. (2010), "Tourisme durable et écotourisme: des méthodes de calcul liées au marketing", Gestion 2000, Vol. 27 No. 1, pp. 85-98

[16] Razali, M. K., \& Khalifah, Z. (2012). Tourists Perception of Service Quality at Nature Park.

[17] Seraphin, H., Platania, M., Spencer, P. and Modica, G. (2018), "Events and tourism development within a local community: the case of winchester (UK)", Sustainability, Vol. 10 No. 10, pp. 3728.

[18] Shyan, N. H., \& Emmanuel. (2011). The Impact of Ecotourism in Malaysia: A Case Study of Mount Kinabalu Malaysia. The International Hospitality and Tourism Student Journal, issue 2, 2011.

[19] What is Ecotourism? | The International Ecotourism Society". www.ecotourism.org. Retrieved 2016-11-17.

[20] World Tourist Organization (2016). Definition on tourism, ecotourism and carrying capacity

[21] W. K. Athula Gnanapala, 2015 American Journal of Marketing Research Vol. 1, No. 1, 2015, pp. 7-19, http://www.aiscience.org/journal/ajmr 